\title{
Ergonomical Evaluation of Power Weeder in Wetland Paddy Condition
}

\author{
K. Upendar", R.C. Dash, D. Behera and A.K. Goel \\ Department of Farm Machinery and Power, CAET, OUAT, Bhubaneswar, India \\ *Corresponding author
}

\section{A B S T R A C T}

\begin{tabular}{|l|}
\hline K e y w or d s \\
$\begin{array}{l}\text { Ergonomical evaluation, } \\
\text { Power weeder, Paddy }\end{array}$ \\
\hline Article Info \\
\hline $\begin{array}{l}\text { Accepted: } \\
\text { 07 October } 2018 \\
\text { Available Online: } \\
10 \text { November } 2018\end{array}$ \\
\hline
\end{tabular}

\section{Introduction}

\section{Weeds and losses due to weeds}

Weeding process is one of the most significant farm operations in crop production. Weed growth is a major problem for both wet land and dry land condition. Weed is a crop which grows in a place, where we don't want and competes for water, nutrient and sunlight. In the absence of an effective weed control measure, weeds consume $30-40 \%$ of applied nutrients resulting in significant yield reduction. Weeding accounts for about $25 \%$ of the total labour requirement of paddy crop (Basavaraj et al., 2016). The labour requirement for weeding depends on weed flora, weed intensity, time of weeding, and soil moisture on the date of weeding and efficiency of the worker.

\section{Weeding methods}

Various common weed control methods are manual, mechanical, chemical and biological. Manual weeding is done by hand or hand tools like hoes and khurpi in the bending posture which involves a lot of drudgery. Manual weeding can give a clean weeding, but it is a very slow process (Biswas, 1990). The principal demerit of chemical weeding is environmental pollution, reduction of microorganism population during the crop season and accumulation of herbicidal residue in the produce.

The mechanical weeding either by hand tools or mechanical weeders is the most effective method both in dry and wet land paddy. Mechanical weed control not only uproots the weeds between the crop rows but also keeps 
the soil surface loose, ensuring better soil aeration and water intake capacity. One of the major constraints in using manually operated weeders is the high physical effort that is needed to push the weeder in the wet and highly resistant soil. It has been reported that the push type Cono-weeders are difficult to use as these have to be moved back and forth and do not work well under conditions of highly dried soil, high inundation of flood water and at the existence of bigger sized weeds (Moody, 1991).

Weeding is very tedious operation as compared to all other agriculture operations. Crop production involves many agricultural operations like tillage, seed bed preparation, sowing, irrigation, and fertilizer application, intercultural operation, harvesting and threshing. Almost all agriculture operations are mechanized and have been performed by the high power prime movers. But, weeding operation, especially for close row spacing crops, weeding operation is very difficult, hence it is performed by the manually operated equipment. Human being had direct physical contact with the equipment and acting as a driver leads to the many musculoskeletal disorders. Drudgery involved in weeding operation increases stress on the worker causing increase in heart rate and oxygen consumption.

\section{Role of ergonomics in agriculture}

Ergonomics or human engineering is the relationship between the man, machine and its working environment. The working environment includes temperature, relative humidity and velocity of surrounding air. The environmental parameters control is not possible for human being, hence the in order to reduce the drudgery being faced by workers can be controlled by adopting good design of equipment that fit to the operator, rather than operator fit to the operation.
Importance of ergonomics has been well organized in industry and military applications. In most of developing countries, agricultural workers constitute one of the important sources of farm power. It is estimated that by 2020 the population of agricultural workers in the country would be about 242 million, of which $50 \%$ would be constitute female workers. Thus there would be a significance role of farm workers in country's agriculture and due attention needs to be given to their capabilities and limitations design of and actual working of equipment in the field to get higher productivity, enhance comfort and better safety. Hence many ergonomical studies have been conducted on comfort and safety of operator during field operations.

Tewari et al., (1991) stated that the performance of weeders is interpreted interms of weeding efficiency and the grade of work relates to rating of work load while worker's comfort is a subjective assessment of operating posture. The physiological cost of work includes the heart rate (HR) and oxygen consumption rate (OCR). Furthermore, severity does not depend on EER; however based on EER severity of work load is classified. Ergonomical evaluation is a tool to evaluate the energy expenditures of workers, their physiological cost and suitability of the method for farm workers and how long they can work continuously without getting fatigue.

Singh (2010) has studied the ergonomical evaluation of Cono-weeder with ten farm women. The mean heart rate of female worker during work was 153 beats/min, and work pulse was 70 beats/min. Higher heart rate may be due to non-performance of both cones of equipment which might need more force in operation. The estimated oxygen consumption rate was $1.0642 \mathrm{l} / \mathrm{min}$ that is $64.7 \%$ of their aerobic capacity $\left(\mathrm{VO}_{2} \max \right)$. The higher average heart rate of a worker in operation of 
this equipment suggests the use of equipment in the small area with adequate rest pause to the worker.

Kumar et al., (2013) have studied the ergonomic evaluation of manually operated weeder under wetland condition. Ergonomic evaluation of weeding operations by different age group of workers at various working hours showed that the heart rates corresponding to Cono- weeder and Mandava weeder were 154.54 beats/min and 140.17 beats/min, respectively. Oxygen consumption rate was $1.76 \mathrm{l} / \mathrm{min}$ and $1.47 \mathrm{l} / \mathrm{min}$, respectively. Working during 12:00 to 2:00 PM with both weeders developed maximum heart rate and oxygen consumption rate as compared to 8:00 - 11:00 AM and 4:00 - 6:00 PM. Agricultural workers of 25 to 30 years age group developed maximum working heart rate and oxygen consumption rate during weeding operations, which were higher than the ages of $30-35$ years and 35 - 40 years.

Haribabu et al., (2015) studied ergonomic evaluation of manual and power operated weeders in dryland condition. The heart rate of workers varied from 109.47 to 130.66 beats/min by using power weeder and 130.33 to 147.52 beats/min by using wheel hoe.

The oxygen consumption rate of workers ranged from 0.873 to $1.302 \mathrm{l} / \mathrm{min}$ with power weeder and 1.389 to $1.738 \mathrm{l} / \mathrm{min}$ with a wheel hoe. The main objective of this study was to evaluate the ergonomical parameters of power weeder.

\section{Materials and Methods}

Ergonomical performance evaluation of the weeder was done in the month of March for three consecutive days. Mean temperature and wind velocity were $40^{\circ} \mathrm{C}$ and $16 \mathrm{~km} / \mathrm{h}$ respectively. The test was conducted during the morning time (10.30 AM). For ergonomic evaluation of weeder, one male subject of age 28 years was selected. The speed of travel $(\mathrm{km} / \mathrm{h})$ was calculated as per RNAM (1983) test code by using a stop watch for covering a known distance. Before actual experiments, subject operated the weeder for $10 \mathrm{~min}$ for warming up, followed by a 5 min rest. Statistical analysis for obtained results was done using SAS 9.0 software and conclusions were listed. The physiological parameters of subject were given in Table 1. The power weeder was evaluated by measuring heart rate, and there after computing oxygen consumption rate and energy expenditure rate. The ergonomic evaluation of weeder with three types of blades i.e. Rectangular blade (B1), blunt edge (B2) serrated blade and sharp edge serrated blade (B3) at two forward speeds $(1.2 \& 1.6 \mathrm{~km} / \mathrm{h})$ was conducted in the field.

\section{Heart rate}

A Polar Heart rate monitor (POLAR, RS 800 CX, Heart monitoring range: 15- 240) was used to measure the heart rate of the operator during field operation. The Polar Heart rate monitor consists of a chest strap (Fig. 1) and a wrist watch (Fig. 2) to receive the data. Initially, heart rate of the subject at rest was measured. Heart rate was measured at every 5 min during operation between $5^{\text {th }}$ and $30^{\text {th }}$ min of operation, and the average reported.

\section{Oxygen consumption rate}

Oxygen consumption the amount of oxygen is consumed by the tissues of the body, usually measured as the oxygen uptake in the lung. The normal value is $250 \mathrm{ml} / \mathrm{min}$ (or 3.5 to 4.0 $\mathrm{ml} / \mathrm{kg} / \mathrm{min}$ ), and it increases with increased metabolic rate. The oxygen consumption rate (amount of oxygen consumed by the subject per unit time) was computed from the heart rate values of the operator and is given by the following equation (Singh et al., 2008). 
Oxygen consumption rate, $(\mathrm{OCR}) \mathrm{l} / \mathrm{min}=$ (0.0114 x HR) - 0.68 (1)

\section{Energy expenditure rate}

The energy expenditure rate indicates the level of bodily stress and in relation to heavy work it can be used to assess the level of effort to work out necessary rest periods, and to compare the efficiency of different tools and ways of arranging the work. The energy expenditure rate (EER) was determined by multiplying the OCR with the calorific value of oxygen as $20.93 \mathrm{~kJ} / \mathrm{l}$ (Nag and Dutt, 1980). The energy expenditure of the subjects obtained was graded as per the tentative classification of strains in different types of jobs given in Indian Council of Medical research (ICMR) report (Table 2).

\section{Statistical analysis}

Randomized block design was used for evaluation of weeder with three different types of blades of power weeder. Statistical analysis carried out by using SAS 9.0 software.

\section{Results and Discussion}

\section{Heart rate of operator}

The heart rate of operator was varied from 131.0 to 145.5 beats/min. The highest heart rate of 142.63 beats/min, 140.27 beats/min and 135.4 beats/min were observed for sharp edge serrated blade, blunt edge serrated and rectangular blade respectively, at forward speed of $1.6 \mathrm{~km} / \mathrm{h}$. Increasing the forward speed of weeder from $1.2 \mathrm{~km} / \mathrm{h}$ to $1.6 \mathrm{~km} / \mathrm{h}$, increased the heart rate by $3.1,5.11$ and 4.76 $\%$ for rectangular blade, blunt edge serrated blade and sharp edge serrated blade, respectively. It data was shown in the Table 3. The factor A (Blade type) and factor B (Forward speed) have significant effect on the heart rate of operator. Kumar et al., (2013) also reported that the maximum heart rate was found to be 154.54 beats/min for cono-weeder, hence it is better to use power weeder as compared to cono-weeder as its operation leads to less fatigue (Fig. 3).

\section{Oxygen consumption rate}

The oxygen consumption of is essentially an absolute measure of workload, whereas heart rate is an indicator of cardiac stress due to physical work load. The oxygen consumption rate of operator for all blades varied from 0.80 to $0.98 \mathrm{l} / \mathrm{min}$ (Fig. 4). The highest oxygen consumption rate of $0.87 \mathrm{l} / \mathrm{min}$ was observed for sharp edge serrated blade, followed by blunt edge serrated blade $(0.84 \mathrm{l} / \mathrm{min})$ and rectangular blade $(0.82 \mathrm{l} / \mathrm{min})$ at forward speed of $1.2 \mathrm{~km} / \mathrm{h}$. Similarly, highest oxygen consumption rate of $0.95 \mathrm{l} / \mathrm{min}$ was noticed for sharp edge serrated blade, followed by blunt edge serrated blade $(0.92 \mathrm{l} / \mathrm{min})$ and rectangular blade $(0.84 \mathrm{l} / \mathrm{min})$ at forward speed of $1.6 \mathrm{~km} / \mathrm{h}$. It was observed that both the factor A (Blade type) and factor B (Forward speed) of weeder have significant effect on the oxygen consumption rate of operator. The data was shown in the Table 4.

Table.1 Physiological parameters of subject

\begin{tabular}{|c|c|}
\hline Variable & Physiological parameters \\
\hline Weight, $\mathrm{kg}$ & 60 \\
\hline Height, $\mathrm{cm}$ & 168 \\
\hline Age, year & 28 \\
\hline BMI & 21.25 (normal weight) \\
\hline
\end{tabular}


Table.2 Tentative classification of strains (ICMR) in different types of jobs

\begin{tabular}{|c|c|c|c|}
\hline Grading & \multicolumn{3}{|c|}{ Physiological response } \\
\hline & $\begin{array}{c}\text { Heart rate, } \\
\text { bpm }\end{array}$ & $\begin{array}{c}\text { Oxygen } \\
\text { uptake, } 1 / \mathrm{min}\end{array}$ & $\begin{array}{c}\text { Energy expenditure, } \\
\mathrm{kcal} / \mathrm{min}\end{array}$ \\
\hline Very light & $<75$ & $<0.35$ & $<1.75$ \\
\hline Light & $75-100$ & $0.35-0.70$ & $1.75-3.5$ \\
\hline Moderately heavy & $100-125$ & $0.70-1.05$ & $3.5-5.25$ \\
\hline Heavy & $125-150$ & $1.05-1.40$ & $5.25-7.00$ \\
\hline Very heavy & $150-175$ & $1.40-1.75$ & $7.00-8.75$ \\
\hline Extremely heavy & $>175$ & $>1.75$ & $>8.75$ \\
\hline
\end{tabular}

Table.3 ANOVA table for heart rate of operator of weeder

\begin{tabular}{|l|l|l|l|l|l|l|}
\hline Source & $\begin{array}{l}\text { Degree of } \\
\text { freedom }\end{array}$ & $\begin{array}{l}\text { Sum of } \\
\text { squares }\end{array}$ & $\begin{array}{l}\text { Mean } \\
\text { square }\end{array}$ & $\begin{array}{l}\text { F cal. } \\
\text { value }\end{array}$ & $\begin{array}{l}\text { F table } \\
\text { value }\end{array}$ & CD \\
\hline Factor A & 2 & 108.181 & 54.091 & 21.7668 & 3.88 & 1.3578 \\
\hline Factor B & 1 & 166.835 & 166.835 & 67.1369 & 4.75 & 1.1086 \\
\hline AB & 2 & 7.301 & 3.651 & 1.4690 & & \\
\hline Error & 12 & 29.820 & 2.485 & & & \\
\hline Total & 17 & 312.138 & & & &
\end{tabular}

Table.4 ANOVA table for oxygen consumption rate of operator of weeder

\begin{tabular}{|l|c|c|c|c|c|c|}
\hline Source & $\begin{array}{l}\text { Degree of } \\
\text { freedom }\end{array}$ & $\begin{array}{l}\text { Sum of } \\
\text { squares }\end{array}$ & $\begin{array}{l}\text { Mean } \\
\text { square }\end{array}$ & $\begin{array}{l}\text { F cal. } \\
\text { value }\end{array}$ & $\begin{array}{l}\text { F table } \\
\text { value }\end{array}$ & CD \\
\hline Factor A & 2 & 0.019 & 0.010 & 21.8777 & 3.88 & 0.0179 \\
\hline Factor B & 1 & 0.017 & 0.017 & 39.5039 & 4.75 & 0.0147 \\
\hline AB & 2 & 0.003 & 0.001 & 3.13160 & & \\
\hline Error & 12 & 0.005 & 0.000 & & & \\
\hline Total & 17 & 0.044 & & & & \\
\hline
\end{tabular}

Table.5 ANOVA table for energy expenditure rate of operator of weeder

\begin{tabular}{|l|c|c|c|c|c|c|}
\hline Source & $\begin{array}{l}\text { Degree of } \\
\text { freedom }\end{array}$ & $\begin{array}{l}\text { Sum of } \\
\text { squares }\end{array}$ & $\begin{array}{l}\text { Mean } \\
\text { square }\end{array}$ & $\begin{array}{l}\text { F cal. } \\
\text { value }\end{array}$ & $\begin{array}{l}\text { F table } \\
\text { value }\end{array}$ & $\begin{array}{l}\text { Critical } \\
\text { Difference }\end{array}$ \\
\hline Factor A & 2 & 0.384 & 0.192 & 28.2474 & 3.88 & 0.0711 \\
\hline Factor B & 1 & 0.562 & 0.562 & 82.5503 & 4.75 & 0.0580 \\
\hline AB & 2 & 0.031 & 0.015 & 2.25060 & & \\
\hline Error & 12 & 0.082 & 0.007 & & & \\
\hline Total & 17 & 1.059 & & & & \\
\hline
\end{tabular}


Fig.1 Chest strap

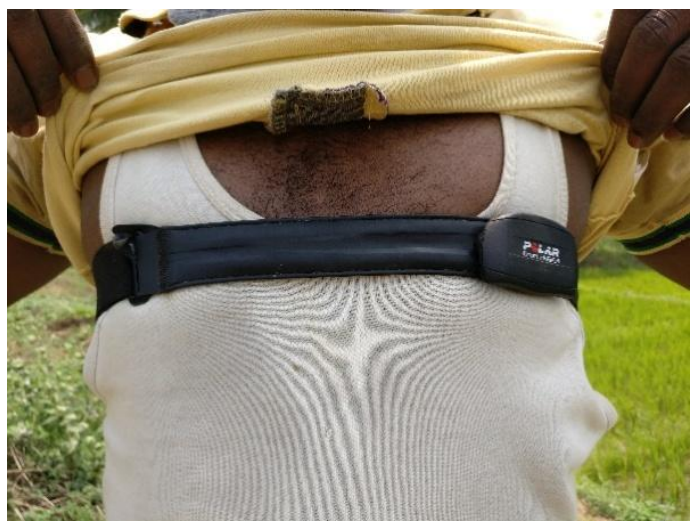

Fig.2 Wrist watch

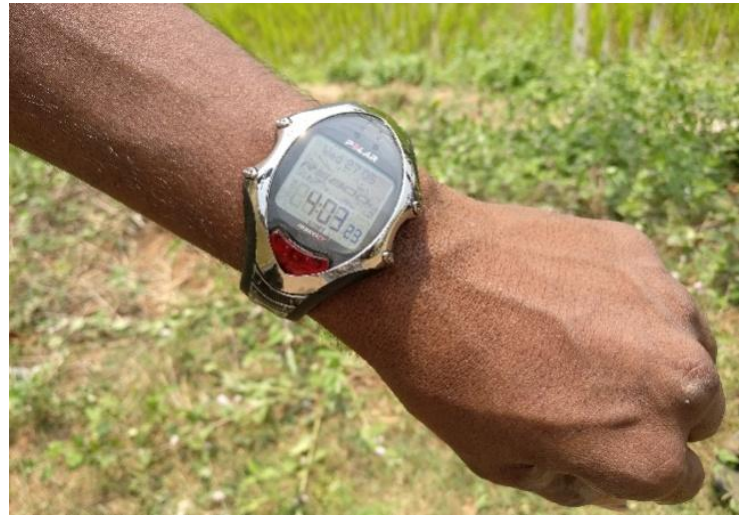

Fig.3 Effect of forward speed of weeder on heart rate of operator



Fig.4 Effect of forward speed of weeder on oxygen consumption rate of operator

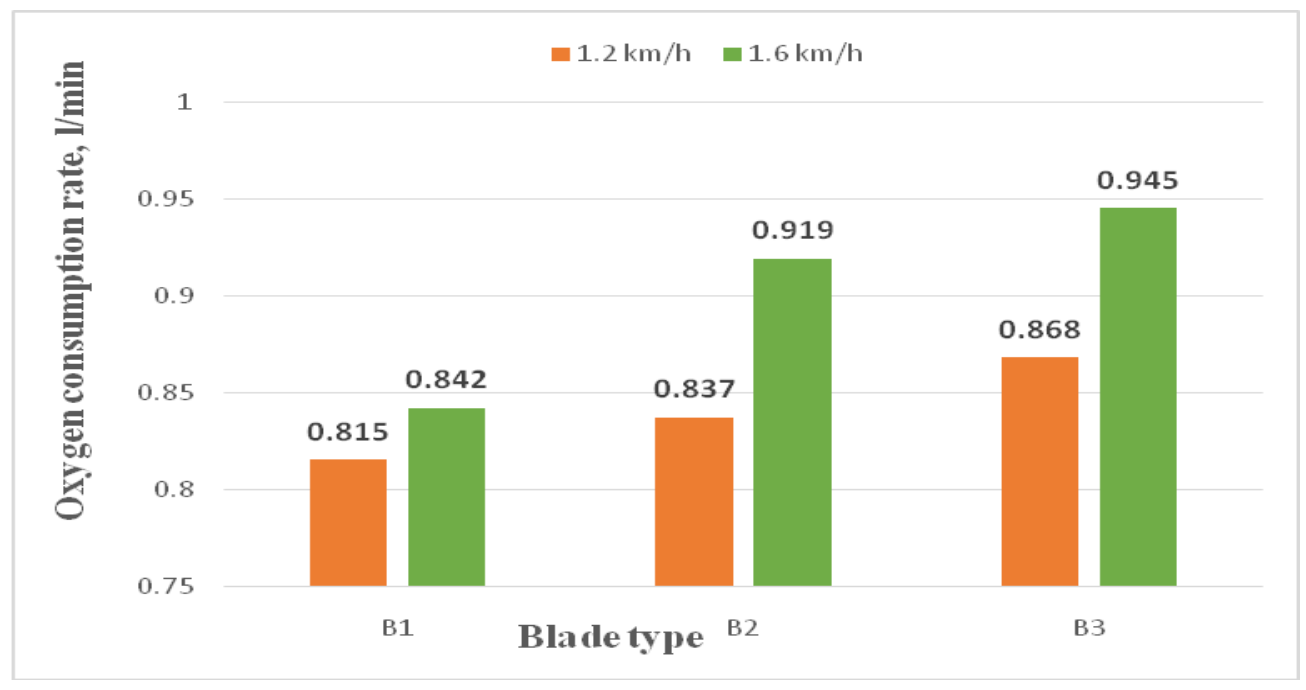


Fig.5 Effect of forward speed of weeder on energy expenditure rate of operator

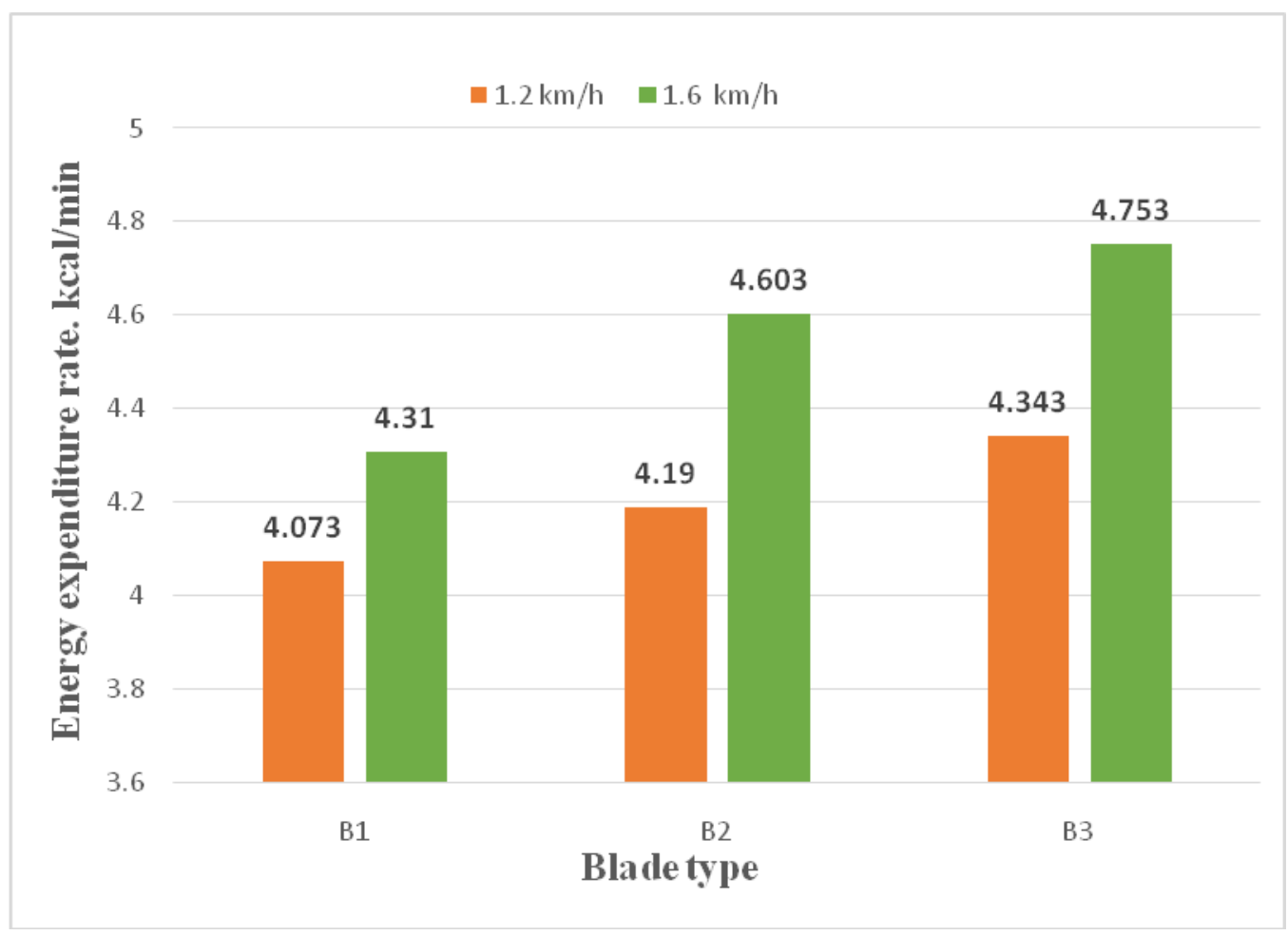

The typical oxygen consumption rate value is $0.2 \mathrm{l} / \mathrm{min}$. During the field operation, it was reaching up to $0.9 \mathrm{l} / \mathrm{min}$, hence, operator must take periodic rest for efficient operation.

\section{Energy expenditure rate}

The energy expenditure rate of operator ranged from 4.01 to $4.90 \mathrm{kcal} / \mathrm{min}$. The highest energy expenditure rate of 4.75 $\mathrm{kcal} / \mathrm{min}$ was observed for sharp edge serrated blade, followed by blunt edge serrated blade $(4.60 \mathrm{kcal} / \mathrm{min})$ and rectangular blade $(4.31$ $\mathrm{kcal} / \mathrm{min}$ ) at forward speed of $1.6 \mathrm{~km} / \mathrm{h}$ (Fig. $5)$.

At $1.2 \mathrm{~km} / \mathrm{h}$ forward speed of weeder the highest energy expenditure rate of 4.34 $\mathrm{kcal} / \mathrm{min}$ was observed for sharp edge serrated blade, followed by blunt edge serrated blade $(4.19 \mathrm{kcal} / \mathrm{min})$ and rectangular blade (4.07 $\mathrm{kcal} / \mathrm{min})$. The blade type and forward speed of weeder have significant effect on the energy expenditure rate of operator. It was observed from Table 5 that the factor $\mathrm{A}$ and factor B have significant effect on the energy expenditure rate of operator.

Ergonomic parameters like heart rate, oxygen consumption rate and energy consumption rate increased with increase of forward speed of weeder for all the treatments. The heart rate of operator was varied from 131.0 to 145.5 beats/min. The oxygen consumption rate of operator varied from 0.80 to $0.98 \mathrm{l} / \mathrm{min}$. The energy expenditure rate of operator was ranged from 4.01 to $4.90 \mathrm{kcal} / \mathrm{min}$.

\section{References}

Anonymous. 1985. RNAM test codes and procedure for farm machinery, Technical series No. 12, Economic and Social Commission for Asia and the Pacific, Regional Network for 
Agricultural Mechanization, Bangkok, Thailand.

Basavaraj, Surendrakumar, A. and Divaker Durairaj, C. 2016. Study of agronomical and soil parameters in paddy field for the development of paddy weeder. International journal of sciences. 30(8): 1627-1631.

Biswas, H.S. 1984. Weed control techniques. Technical Bulletin No, CIAE/84/46, Central Institute of Agricultural Engineering, Bhopal.

Haribabu, B., Jaya Prakash, R., Anil Kumar, D. and Prasad, P. 2015. Ergonomical evaluation of manual and power operated weeders in dry land condition. International Journal of Agricultural Engineering. 8(2): $169-174$.

Kumar, A., Haribabu, B., Srinivasa, R.A. and Someswararao, Ch. 2013. Ergonomic evaluation of manually operated weeder under wetland condition. Scientific Research and Essays. 8(6): 249 -255.

Moody K. 1991. Weed management in rice. pp. 301-328. In: Handbook of Pest Management in Agriculture (Ed. Pimental D), CRC Press, and Florida.

Nag, P.K. and Dutt, P. 1979. Effective of some simple Agricultural weeders with reference to physiological responses. Journal of Human Ergonomics. 13-2.

Singh, S.P. 2010. Ergonomical Evaluation of Cono-Weeder with Farm Women. Sub centre of Directorate of Research on Women in Agriculture, CIAE, 34(3):3136.

Tewari, V.K., Datta, R.K. and Murthy, A.S.R. 1993. Field performance of weeding blades of a manually operated push-pull weeder. Journal of Agricultural Engineering Research. 55:129-141.

\section{How to cite this article:}

Upendar, K., R.C. Dash, D. Behera and Goel, A.K. 2018. Ergonomical Evaluation of Power Weeder in Wetland Paddy Condition. Int.J.Curr.Microbiol.App.Sci. 7(11): 855-862. doi: https://doi.org/10.20546/ijcmas.2018.711.101 